\title{
PEMBENTUKAN SIKAP TOLERANSI DAN BERSAHABAT DALAM PEMBELAJARAN PENDIDIKAN KEWARGANEGARAAN DI SD/MI
}

\section{ESTABLISHMENT OF TOLERANCE AND FRIENDLY ATTITUDES IN THE LEARNING OF CITIZENSHIP EDUCATION IN ELEMENTARY SCHOOLS}

\author{
Elis Tsamrotul Aeni \\ Fakultas Agama Islam Universitas Ibn Khaldun Bogor \\ Jl. Sholeh Iskandar, RT.01/RW.10, Kedungbadak, Kec. Tanah Sereal, Kota Bogor, Jawa Barat \\ Email: elistsamrotul88@gmail.com
}

Submitted: 30-03-2021, Revised: 27-4-2021, Accepted: 04-05-2021

\begin{abstract}
Abstrak
Sikap manusia merupakan pengaruh utama bagi perilaku baik dan buruk manusia sehari-hari. Sikap tersebut tidak dimiliki oleh manusia sejak lahir, melainkan harus melakukan pembentukan. Tujuan penelitian ini adalah mendeskripsikan pembentukan sikap toleransi dan bersahabat dalam pembelajaran pendidikan kewarganegaraan di SD/MI. Jenis penelitian yang digunakan pada penelitian ini merupakan penelitian kualitatif deskriptif dengan pendekatan yang digunakan yaitu studi lapangan. Instrumen yang digunakan adalah observasi, wawancara, dan dokumentasi. Penggunaan analisis data dilakukan dengan menggunakan teori Miles yaitu pengumpulan data, reduksi data, display data, dan kesimpulan atau verifikasi. Penelitian dilakukan pada dua tempat yaitu MI Tarbiyatul Aulad dan SDN Cimandala 03 yang dilakukan pada kelas III. Berdasarkan hasil penelitian yang telah dilakukan, diperoleh bahwa dalam pembelajaran pendidikan kewarganegaraan terdapat pembentukan sikap toleransi dan bersahabat. Dengan terlaksananya program sekolah seperti perayaan hari nasional, pentas seni, dan santunan, serta buku penghubung antara orang tua dan guru, sehingga dapat dijadikan sebagai penguatan terhadap sikap toleransi dan bersahabat yang sudah ditanamkan oleh guru di dalam pembelajaran pendidikan kewarganegaraan.
\end{abstract}

Kata Kunci: Sikap, Toleransi, Bersahabat, Pendidikan Kewarganegaraan

\begin{abstract}
Human attitudes are the primary influence of human good and bad behavior every day. Humans do not own this attitude from birth but through formation. This study aimed to describe the formation of tolerant and friendly attitudes in learning Citizenship Education in SD/MI. This study used descriptive qualitative research through field studies. The instruments in this research were observation, interview, and documentation. Data analysis was carried out using Miles theory, namely data collection, data reduction, data display and conclusion or verification. The research was conducted in two places, namely MI Tarbiyatul Aulad and SDN Cimandala 03, conducted in the third-grade students. Based on the research results, it was found that there was a formation of tolerance and friendly attitudes in Citizenship Education learning. With the implementation of school programs such as national day celebrations, performing arts, compensation and liaison books between parents and teachers, they could reinforce the tolerance and friendship instilled by teachers in Citizenship Education learning.
\end{abstract}

Keywords: Attitude, Tolerance, Friendly, Citizenship Education

How to Cite: Aeni, E. T. (2021). Pembentukan Sikap Toleransi dan Bersahabat dalam Pembelajaran Pendidikan Kewarganegaraan di SD/MI. AULADUNA: Jurnal Pendidikan Dasar Islam, 8(1), 39-50. 


\section{Pendahuluan}

Lembaga Pendidikan menanggung amanah untuk menyiapkan siswa untuk mampu bertahan hidup serta membentuk karakter yang sesuai dengan nilai-nilai yang berlaku secara humanis, global, lokal, dan nasional (Tilaar, 2012). Institusi pendidikan berfungsi sebagai induk pengembangan, dan pembentukan identitas budaya suatu negara atau komunitas. Melalui pendidikan nasional, setiap bangsa menciptakan strategi pengembangan sumber daya manusia yang memiliki seperangkat karakter dan kompetensi untuk berperan aktif dalam perwujudan tatanan sosial yang adil dan beradab. Sistem pendidikan nasional pada hakikatnya merupakan pencerminan dari upaya sadar sebuah bangsa untuk membentuk keberlanjutan warisan budaya dan jati diri sebagai bangsa bermartabat dan berdaulat (Musanna, 2017). Mengacu pada undangundang nomor 20 tahun 2003 tentang sistem pendidikan nasional fungsi pendidikan pada pasal 3 yang menyatakan bahwa pendidikan nasional berfungsi mengembangkan kemampuan dan membentuk watak serta peradaban bangsa yang bermartabat dalam rangka mencerdaskan kehidupan bangsa, bertujuan untuk berkembangnya potensi siswa agar menjadi manusia yang beriman dan bertakwa kepada Tuhan Yang Maha Esa, berakhlak mulia, sehat, berilmu, cakap, kreatif, mandiri, dan menjadi warga negara yang demokratis serta bertanggung jawab (Sujana, 2019).

Proses pembelajaran di dalam dunia pendidikan sangat penting dilakukan, agar tujuan pendidikan di Indonesia akan tercapai. Dalam pendidikan jenjang SD/MI terdapat lima mata pelajaran yang wajib dipelajari siswa dalam kurikulum 2013 ini, salah satunya yaitu mata pelajaran pendidikan kewarganegaraan atau biasa disingkat $\mathrm{PKn}$. Salah satu pembelajaran yang menerapkan pembentukan karakter yaitu pembelajaran $\mathrm{PKn}$, dalam pembelajaran ini terdapat pembentukan nilai-nilai dasar kebangsaan dan moral di dalamnya melalui materi-materi tentang kebangsaan serta Pancasila. Mata pelajaran PKn terdapat di berbagai jenjang pendidikan termasuk dalam madrasah ibtidaiyah. Seluruh pendidikan sekolah dasar pasti terdapat pembelajaran PKn. Seperti di MI Tarbiyatul Aulad dan SDN Cimandala 03. Pada sekolah tersebut, pendidik melakukan upaya-upaya untuk pembentukan sikap terhadap siswa.

Sikap merupakan bagian sentral dari identitas manusia (Rahman, 2019), sehingga menjadi pengaruh utama bagi perilaku atau tindakan manusia sehari-hari, sikap juga dapat membedakan seseorang dengan orang yang lainnya serta dapat menunjukkan bagaimana seseorang bertingkah laku. Orang yang memiliki keyakinan yang stabil sudah pasti akan memiliki sikap yang mulia dan sebaliknya orang yang tidak memiliki keyakinan yang stabil sikapnya tidak akan mulia (Dahlan, 2017). Artinya, perilaku merupakan perwujudan dari sikap, seperti orang yang berperilaku tidak jujur, kejam, dan tidak senang berbagi tentulah ia mewujudkan sikap yang buruk. Sebaliknya, apabila orang yang berperilaku jujur, suka menolong tentu orang tersebut mewujudkan sikap mulia. Menurut Jud dalam Rahman (2018), sikap merupakan reaksi efektif yang bersifat positif, negatif, ataupun campuran yang berisi perasaan pada suatu obyek. Kecenderungan berperilaku terhadap suatu objek tertentu. Reaksi kognitif sebagai penilaian terhadap suatu obyek yang didasarkan pada ingatan, pengetahuan, dan kepercayaan yang relevan.

Sikap seseorang terhadap sesuatu dibentuk oleh lingkungan di sekitarnya (Purwanto, Ichsan, Gomes, Rahman, \& Irwandani, 2020). Sikap baik dan buruk tidak dimiliki seseorang sejak lahir, melainkan harus melakukan pembentukan. Menurut Nata (2015), sikap baik dan buruk menjadi relatif dan nisbi pula, yakni baik dan buruk yang dapat terus berubah. Maka dari itu, pembentukan sikap ini salah satunya bisa didapatkan 
melalui pendidikan. Di dalam rumah, sikap seseorang dapat terbentuk dengan cara dasar salah satunya mematuhi peraturan-peraturan yang ada di rumah, seperti dibiasakan untuk membersihkan kamar pribadi dan tidak boleh berkata kasar. Anak akan terbiasa untuk melakukan kegiatan tersebut, sehingga melalui pembiasaan itu dapat terbentuk sikap baik dan mulia pada dirinya, karena kegiatan pembiasaan tersebut merupakan contoh pendidikan yang diajarkan oleh orang tua dan keluarga di dalam rumah sebagai upaya pembentukan sikap pada anak. Lingkungan rumah dan keluarga memiliki andil yang sangat besar dalam pembentukan perilaku anak (Subianto, 2013). Selain di rumah, pembentukan sikap juga dapat dilakukan melalui pendidikan di sekolah, karena siswa terbiasa untuk melakukan sikap-sikap yang baik melalui proses pembelajaran di kelas, peraturan yang sudah diterapkan oleh sekolah, dan kegiatan program sekolah yang mendukung pembentukan sikap siswa. Dengan adanya pembiasaan, maka siswa akan terbiasa melakukan kegiatan tersebut, sehingga dapat terbentuk sikap baik dan mulia pada siswa. Terdapat 18 karakter atau sikap yang menjadi target sekaligus indikator keberhasilan pendidikan karakter seperti yang dikemukakan dalam Kementrian Pendidikan Nasional 2013 (Zaman, 2019). Melihat pada kondisi saat ini, ternyata pendidikan yang sudah ditanamkan dengan 18 karakter belum sampai kepada harapannya, masih banyak sikap yang tidak terjadi di kalangan siswa salah satunya adalah sikap toleransi dan bersahabat.

Salah satu sikap yang menjadi target sekaligus indikator keberhasilan bagi bangsa yaitu toleransi. Toleransi merupakan sikap menghargai dan menghormati keragaman yang ada di lingkungan, baik itu secara agama, ras, bahasa, kebudayaan dan lain sebagainya selama tidak mengganggu dan melanggar norma yang berlaku (AlAnsori, 2018). Seseorang yang memiliki toleransi, tidak merasa tidak nyaman dengan keberadaan orang lain yang memiliki bahasa, agama, ras, kepercayaan dan pemahaman yang berbeda (Shaukat \& Pell, 2020; Taş \& Minaz, 2019). Michele dalam Wijaya, Fahreza, \& Kistian (2019) berpendapat bahwa seseorang dapat memperlakukan orang lain dengan baik, penuh pengertian, dan hormat melalui toleransi. Toleransi tidak melarang seseorang melakukan penilaian moral, tetapi menuntut agar menghargai perbedaan. Kebajikan ini membantu anak memahami bahwa semua orang berhak mendapatkan kasih sayang, keadilan, dan rasa hormat meskipun bisa saja tidak sependapat dengan keyakinan atau perilaku mereka. Seseorang yang toleran akan selalu membuat pemikiran dan penilaian pribadi secara cermat dalam setiap pengambilan keputusan (Mahpudz, Jamaludin, \& Palimbong, 2019).

Dari beberapa pendapat diperoleh bahwa toleransi adalah salah satu sikap yang harus dimiliki dan tertanam pada diri setiap siswa untuk saling menghormati dan menghargai perbedaan baik secara individu maupun secara kelompok seperti pada semboyan negara Indonesia yaitu "Bhineka Tunggal Ika" yang memiliki arti walaupun berbeda-beda tapi tetap satu jua (Salim, 2017). Setiap siswa memiliki latar belakang, ciri khas, agama, suku dan bahasa yang berbeda-beda, maka dari itu setiap siswa harus saling menghargai satu sama lain. Sikap toleransi akan melahirkan sikap yang lain diantaranya yaitu persahabatan.

Bersahabat dapat dilakukan oleh siapa saja tidak memandang warna kulit, budaya, ras dan lain sebagainya. Baron \& Byrne dalam Pranata \& Barus (2019) mengidentifikasikan bahwa bersahabat adalah hubungan yang menjadikan dua orang atau lebih habiskan waktu bersama, berinteraksi, dan saling mendukung dalam berbagai situasi. Dalam persahabatan dapat terjalin kerjasama dengan teman, bergaul, dan bertukar pendapat, serta akan memiliki perasaan senang, saling melengkapi, harus 
saling jujur, dan saling terbuka. Jika salah satu orang di dalam persahabatan tersebut memiliki sikap egois, tidak mau mengalah, tidak jujur, dan terbuka, serta rendahnya sikap toleransi, maka persahabatan itu akan hilang dan selesai, sehingga dampak dari hilangnya persahabatan akan membentuk seseorang menjadi pribadi yang individualis. Seseorang yang memiliki sikap individualis biasanya melakukan kegiatan berdasarkan kehendak pribadinya tanpa memikirkan orang lain (Idris, 2013).

Penanaman sikap toleransi dan bersahabat dapat dilakukan melalui pendidikan, salah satunya yaitu pendidikan formal atau sekolah. Dalam undang-undang nomor. 20 tahun 2003 pasal 3 dijelaskan bahwa pendidikan nasional berfungsi untuk mengembangkan kemampuan dan membentuk watak serta kebudayaan bangsa yang bermartabat dalam rangka mencerdaskan kehidupan bangsa, bertujuan untuk berkembangnya potensi siswa, agar menjadi manusia yang beriman, bertakwa kepada Tuhan Yang Maha Esa, berakhlak mulia, sehat, berilmu, cakap kreatif, mandiri dan menjadi warga negara yang demokratis serta bertanggung jawab (Supardi, 2015). Mengembangkan dan membentuk watak siswa dapat disalurkan melalui pembiasaan yang dapat dilakukan melalui proses pembelajaran sehari-hari yang terdapat di sekolah, sehingga siswa dapat terbiasa untuk menjalankan sikap baik tersebut. Sekolah adalah suatu lembaga yang didirikan untuk proses pembelajaran anak dibawah pengawasan guru dengan tujuan untuk meningkatkan kecerdasan serta pembentukan moral dan karakter anak agar menjadi individu yang lebih berkualitas (Dahlan, 2016). Sehingga, jika sekolah menerapkan pembelajaran dengan baik, maka sikap yang dibentuk oleh guru dapat mencapai tujuan yang diharapkan. Berdasarkan uraian yang telah dipaparkan, maka peneliti akan mendeskripsikan pembentukan sikap toleransi dan bersahabat dalam pembelajaran pendidikan kewarganegaraan di SD/MI.

Penelitian yang dilakukan oleh Yunida (2017) menunjukkan adanya pengaruh yang signifikan antara peran orang tua dalam membentuk sikap toleransi anak. Kesimpulan membentuk sikap toleransi anak melalui peran orang tua, yaitu: (1) orang tua sebagai contoh atau panutan bagi anak, (2) peran sebagai pengawas, dan (3) peran sebagai pembimbing. Penelitian Mahfiroh (2018) menunjukkan bahwa pembentukan karakter bersahabat melalui budaya sekolah di SMP Al-Islam Kartasura yaitu melakukan penanaman interaksi yang baik dengan menggunakan bahasa yang santun, berkomunikasi dengan kata-kata yang positif, saling menghargai dan menjaga kehormatan antar teman, dan saling bertoleransi seperti peduli dan memberikan bantuan kepada teman. Penelitian yang dilakukan oleh Sunarti (2019) memiliki hasil yang menunjukkan bahwa pembentukan karakter yang diwujudkan dari pembelajaran pendidikan kewarganegaraan dapat menggunakan metode pembiasaan, keteladanan, hukuman, anjuran, perintah langsung, menciptakan suasana kondusif, dan terintegrasi, serta terinternalisasi.

Berdasarkan uraian di atas, dapat disimpulkan bahwa lemahnya sikap toleransi dan bersahabat yang tertanam pada siswa, sehingga peneliti melakukan penelitian mengenai pembentukan sikap toleransi dan bersahabat dalam pembelajaran pendidikan kewarganegaraan di SD/MI. Tujuan dari penelitian ini yaitu mendeskripsikan pembentukan sikap toleransi dan bersahabat dalam pembelajaran pendidikan kewarganegaraan terhadap siswa MI Tarbiyatul Aulad dan SDN Cimandala 03.

\section{Metode Penelitian}

Dalam penelitian ini menggunakan metode kualitatif deskriptif. Penelitian dengan menggunakan metode tersebut bertujuan untuk mengumpulkan informasi yang 
dapat disusun, dianalisis, dan dipaparkan untuk mendeskripsikan bagaimana pembentukan sikap toleransi dan bersahabat dalam pembelajaran pendidikan kewarganegaraan di SD/MI (Marwa, Munirah, Angriani, Suharti, Sriyanti, \& Rosdianaet, 2020). Lokasi yang digunakan dalam penelitian terdiri dari dua tempat yaitu MI Tarbiyatul Aulad Nanggewer dan SDN Cimandala 03. Sumber data yang digunakan yaitu guru kelas tiga, kepala sekolah, bidang kurikulum, dan siswa kelas tiga.

Adapun pendekatan yang digunakan oleh peneliti adalah pendekatan studi lapangan. Teknik pengumpulan data dalam penelitian ini yaitu observasi, wawancara, dan dokumentasi. Jenis observasi yang digunakan yaitu non partisipan yang berarti peneliti hanya sebagai pengamat independen (Intan \& Marhaeni, 2015). Informan wawancara pada penelitian ini yaitu wali kelas tiga, kepala sekolah, bidang kurikulum, dan siswa kelas tiga MI Tarbiyatul Aulad dan SDN Cimandala 03. Jenis wawancara yang digunakan yaitu wawancara tidak terstruktur, karena pada saat pelaksanaan pengumpulan data dilakukan secara fleksibel dan tidak terpaku dengan pertanyaanpertanyaan khusus. Dokumentasi pada penelitian ini bertujuan untuk menyempurnakan data yang didapatkan dari observasi dan wawancara berupa foto dan dokumen terkait proses pembentukan sikap toleransi dan bersahabat.

Triangulasi data dilakukan dengan melibatkan kepala sekolah, bidang kurikulum, dan siswa kelas tiga. Analisis data dilakukan dengan menggunakan teori Mels dalam Rijali (2018) yaitu pengumpulan data, reduksi data, display data, dan kesimpulan atau verifikasi.

\section{Hasil dan Pembahasan}

\subsection{Hasil}

Setelah melaksanakan penelitian yang dilakukan di MI Tarbiyatul Aulad dan SDN Cimandala 03, peneliti menemukan hasil yang menunjukkan bahwa dalam pembelajaran pendidikan kewarganegaraan sikap toleransi dan bersahabat dapat terbentuk. Dari hasil data ditemukan bahwa pembentukan sikap toleransi dan bersahabat dilakukan dalam tiga model, yakni sebagai berikut:

\subsubsection{Proses}

Terkait model kurikulum yang digunakan pada kedua sekolah, peneliti mendapatkan hasil wawancara yang disampaikan oleh bapak A selaku guru kelas tiga MI Tarbiyatul Aulad dan bapak F selaku guru kelas tiga SDN Cimandala 03 yakni sekolah menggunakan kurikulum 2013. Pada kurikulum tersebut, terdapat beberapa sikap yang harus dicapai pada setiap mata pelajaran, diantaranya adalah sikap toleransi dan bersahabat.

Tujuan dari penanaman sikap toleransi dan bersahabat sebagai bekal hidup dari sekarang hingga tua nanti dan penanaman sikap ini harus ditanamkan sejak sekolah dasar agar seiring dengan berjalannya waktu anak tersebut dapat terbiasa melakukannya, sehingga membentuk pribadi yang baik, akhlak yang baik pula, dan membuat dirinya menjadi berkualitas, baik pada kalangan keluarga maupun lingkungan. Penanaman sikap ini sangat penting dibentuk sejak sekolah dasar yang dalam pembelajaran PKn kelas III terdapat materi yang berkaitan dengan pembentukan sikap toleransi dan bersahabat.

Materi yang sejalan dengan pembentukan sikap toleransi dan bersahabat pada pembelajaran pendidikan kewarganegaraan. Materi pertama yaitu Pancasila. Pada materi ini, guru menjelaskan terkait bunyi Pancasila, kandungan Pancasila, dan contoh 
kegiatan nyata yang terdapat pada nilai-nilai Pancasila. Pemberian contoh kegiatan yang dilakukan oleh guru berupa contoh peristiwa yang dialami guru ataupun contoh nyata yang terdapat pada sekitar lingkungan sekolah ataupun rumah, bertujuan agar siswa dapat memahami maksud sikap yang guru jelaskan serta guru tanamkan pada siswa. Materi kedua yaitu keberagaman. Jenis keberagaman yang diajarkan pada pembelajaran pendidikan kewarganegaraan yaitu keberagaman budaya, suku, bahasa, makanan daerah, baju adat, dan tarian adat. Bentuk sikap toleransi yang pasti akan diajarkan harus menanamkan kebiasaan untuk saling menghargai, menghormati, tolong menolong, dan menerima berbagai keragaman yang ada di kelas seperti agama, warna kulit, bahasa, budaya, dan perbedaan fisik satu sama lain. Pembentukan sikap bersahabat yang ditanam, seperti tidak memilah teman, menumbuhkan rasa saling menyayangi, berteman dengan siapa saja tanpa membeda-bedakan, dan selalu berbuat baik. Jika seseorang melakukan perbuatan baik, maka Allah swt. akan sayang kepadanya.

Menurut pendapat guru kelas tiga MI Tarbiyatul Aulad yang berinisial bapak A, faktor yang sangat berperan penting terhadap pembentukan sikap siswa itu ada sekolah, rumah dan lingkungan artinya dapat dikatakan guru dan orang tua sebagai pengontrol pembentukan sikap toleransi dan bersahabat pada siswa. Pendapat guru kelas tiga SDN Cimandala 03 bapak F pun sejalan dengan pendapat bapak A dari MI Tarbiyatul Aulad, sehingga yang bertanggung jawab dan sangat berperan penting atas terbentuknya sikap jika di sekolah adalah guru, karena guru yang mampu mengontrol anak ketika sedang berada di sekolah. Berbeda jika di rumah dan lingkungan, orang yang berperan penting pada pembentukan sikap serta yang bertugas untuk mengontrolnya adalah orang tua. Orang tua memiliki banyak waktu bersama-sama. Dengan adanya intensitas waktu yang banyak, orang tua sebisa mungkin dapat menjalankan peran dan tugasnya dengan sebaik-baiknya, begitupun guru harus mendidik anak di sekolah dengan sebaik-baiknya.

\subsubsection{Implementasi}

Strategi guru terhadap implementasi pembentukan sikap toleransi dan bersahabat pada pembelajaran pendidikan kewarganegaraan adalah menciptakan suasana pembelajaran secara berkelompok, karena pada saat pembelajaran kelompok siswa dapat berbaur dengan seluruh siswa di kelas. Pada satu kelompok biasanya guru menggabungkan berbagai macam latar belakang berbeda yang dimiliki oleh siswa, sehingga dalam pembelajaran siswa dapat saling membantu, saling menghargai, dan menolong teman pada kelompoknya dan tidak memilih-milih teman, sehingga dapat menciptakan suasana saling sayang menyayangi antarsiswa. Seperti yang terlihat pada gambar berikut:

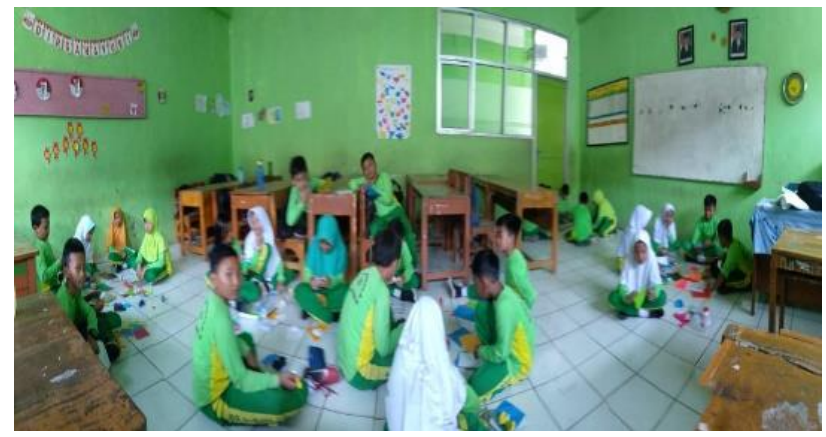

Gambar 1. Pembelajaran Kelompok 
Seiring berjalannya waktu, cara seperti itu cukup efektif untuk pembentukan sikap toleransi dan bersahabat seperti saling menghargai, tolong menolong, menghormati keberagaman, dan saling berteman dengan siapapun tanpa harus membeda-bedakan.

Anak akan mudah memahami materi jika cara penyampaian yang dilakukan oleh guru menyenangkan dan mudah dipahami. Oleh karena itu, dalam penyampaian materi pendidikan kewarganegaraan biasanya guru menggunakan metode bercerita. Guru menyampaikan materi yang dipelajari pada hari itu dengan cara bercerita dan memberikan contoh-contoh yang terdapat pada lingkungan sekitar. Contohnya, kisah tentang Bilal bin Rabah. Berdasarkan kisah tersebut, dapat diperoleh nilai saling menghargai perbedaan fisik, sehingga membuat siswa lebih mudah untuk menerima materi yang disampaikan oleh guru dan contoh sikap nyata dapat dirasakan oleh siswa. Siswa juga dapat mempraktikannya pada kehidupan sehari-hari.

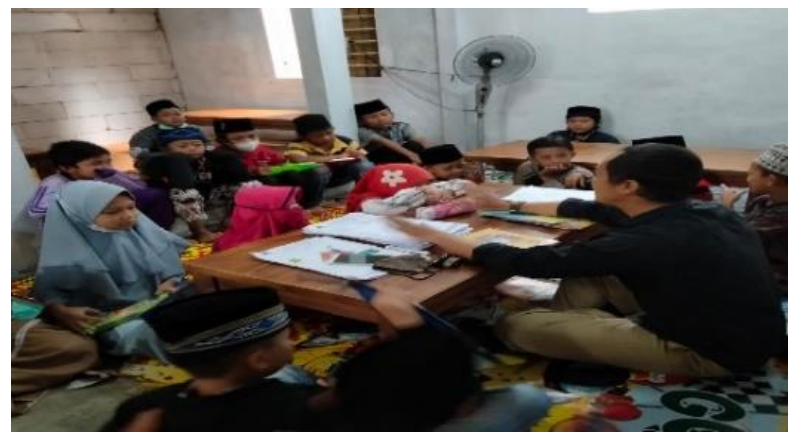

Gambar 2. Metode Bercerita

Selain dengan metode yang menyenangkan pada saat pembelajaran, guru melakukan upaya lain agar membiasakan anak untuk melakukan pembentukan sikap, salah satunya melakukan pembiasaan rutinitas sebelum memulai pembelajaran, seperti membaca Asmaul Husna, melakukan shalat duha, membaca shalawat, dan membaca Pancasila. Pada saat proses pembelajaran perlu diberikan jeda waktu agar siswa tidak bosan, kegiatan untuk mengisi jeda tersebut biasanya menyanyikan lagu daerah dari perwakilan siswa yang ada di kelas. Tidak hanya guru, sekolah juga melakukan beberapa program yang bertujuan untuk pembentukan karakter pada siswa. Program yang dilakukan oleh sekolah antara lain kegiatan santunan, perayaan hari nasional, dan pentas seni, serta buku penghubung antara orang tua dan guru di sekolah.

Terdapat beberapa kendala pada saat pembentukan sikap toleransi dan bersahabat dalam pembelajaran pendidikan kewarganegaraan yang dialami guru terhadap siswa, seperti perbedaan penangkapan materi pada setiap siswa, sehingga pada akhir pembelajaran ada yang dapat menerapkannya pada kehidupan sehari-hari dan adapula yang menerapkan sikap yang ditanamkan hanya di sekolah saja. Jika terdapat siswa yang tidak melakukan sikap yang baik di sekolah, biasanya guru memberikan hukuman kepada siswa, seperti siswa harus membaca istighfar selama tiga puluh kali atau membayar kotak punishment yang sudah dibuat oleh guru. Pemberian hukuman tersebut bertujuan agar siswa tidak terbiasa dengan perbuatan yang tidak baik. Tetapi jika terdapat siswa yang melakukan perbuatan baik, guru memberikan reward berupa bintang. Pada setiap akhir pekan pembelajaran siswa dapat menukar bintang yang dimiliki dengan hadiah yang sudah dipersiapkan oleh guru. 
Dalam pembentukan sikap toleransi dan bersahabat kepribadian seorang guru dapat berpengaruh dengan hasil yang didapatkan oleh siswa. Kepribadian seorang guru akan melahirkan nilai untuk dirinya ketika siswa melihat sosok pribadi guru yang mengajarnya seperti apa dan siswa pun dapat menilai guru yang mengajarnya sebagai guru, sehingga guru harus melakukan hal dan sikap yang baik, karena bagaimanapun secara sadar maupun tidak sadar, siswa akan meniru tingkah laku serta perkataan yang sudah guru lakukan. Selain itu, guru juga harus dekat dan berkomunikasi baik dengan siswa serta sayangilah siswa dengan sepenuh hati. Jika guru menyayangi siswa dengan sepenuh hati, maka perasaan itu akan sampai kepada siswa dan siswa pun dapat menyayangi guru dengan sendirinya.

MI Tarbiyatul Aulad dan SDN Cimandala 03 melakukan beberapa upaya agar anak dapat secara maksimal tertanamnya karakter yang baik pada dirinya, dengan cara mengadakan beberapa program yang bernilaikan karakter. Program pertama yaitu perayaan hari nasional. Siswa melakukan kegiatan perayaan hari nasional pada saat perayaan Hari Kartini, yakni siswa menggunakan pakaian adat khas dari daerah yang sudah ditentukan oleh gurunya, sehingga siswa dapat mengenal dan melihat secara langsung berbagai macam jenis keragaman pakaian adat yang ada di Indonesia. Program kedua yaitu pentas seni. Kegiatan pentas seni biasanya menampilkan berbagai macam keahlian yang dimiliki oleh siswa, salah satunya pementasan tarian-tarian adat yang dilakukan oleh siswa secara berkelompok. Kegiatan pentas seni membantu siswa untuk mengetahui berbagai keragaman tarian adat yang terdapat di Indonesia. Program ketiga yaitu santunan. Kegiatan santunan biasanya diadakan satu tahun sekali, biasanya dilakukan pada saat menjelang bulan puasa. Kegiatan santunan diberikan kepada siswa yang yatim atau piatu dan siswa yang kurang mampu. Dari kegiatan santunan, siswa dilatih untuk berbagi kepada sesama dan saling tolong menolong tidak memandang siapa yang mereka bantu. Program keempat yaitu pengadaan buku penghubung. Buku penghubung merupakan salah satu alat penghubung antara guru dan orang tua. Dalam buku tersebut, biasanya guru memberikan pesan-pesan apa saja yang hari ini dilakukan oleh anaknya di kelas, serta melalui buku tersebut guru juga dapat menitipkan pesan, seperti guru sedang melakukan pembentukan sikap toleransi dan bersahabat di sekolah, maka guru meminta support kepada orang tua agar melanjutkan kegiatan yang sudah dilakukan oleh guru di sekolah supaya siswa dapat terbiasa untuk melakukan kegiatan yang mencerminkan sikap toleransi dan bersahabat.

\subsubsection{Evaluasi}

Cara guru mengevaluasi keberhasilan dari pembentukan sikap toleransi dan bersahabat dalam pembelajaran yaitu dengan melakukan dua jenis evaluasi. Pertama, jika pengevaluasian dilihat dari segi implementasi, maka dengan cara visualisasi atau melihat dari sikap keseharian siswa di sekolah. Kedua, jika pengevaluasian berupa tulisan itu dicantumkan pada rapor siswa. Selain itu, terdapat tindak lanjutan kepada siswa yang belum mencapai sikap yang diharapkan dengan cara berdiskusi dengan orang tua tentang pribadi siswa tersebut, sehingga guru dan orang tua dapat mengambil jalan tengah dari permasalahan yang dialami oleh siswa.

Selain mengadakan program yang meningkatkan nilai karakter siswa, guru mempunyai upaya lain untuk membiasakan anak dalam melakukan pembentukan sikap, seperti melakukan pembiasaan rutinitas sebelum memulai pembelajaran, contohnya membaca Asmaul Husna, melakukan shalat duha, membaca shalawat, dan membaca 
Pancasila. Pembentukan sikap toleransi dan bersahabat dapat dibentuk melalui proses pembelajaran, implementasi pembelajaran, dan evaluasi pembelajaran.

\subsection{Pembahasan}

Peneliti melakukan pengumpulan data dalam tiga teknik yaitu observasi, dokumentasi, dan wawancara. Pada studi observasi, didapatkan data tentang eksistensi kedua sekolah dan mengamati bagaimana guru memberikan pembelajaran pada mata pelajaran pendidikan kewarganegaraan. Pada studi dokumentasi, ditemukan keberhasilan sekolah sebagai lembaga pendidikan dan peneliti mendapatkan foto hasil wawancara serta foto dokumen yang mendukung dalam penelitian ini. Pada studi wawancara, didapatkan data terkait dengan pembentukan sikap toleransi dan bersahabat dalam pembelajaran pendidikan kewarganegaraan. Hasil data ini kemudian dilakukan triangulasi kepada kepala sekolah, bidang kurikulum, dan siswa untuk menguatkan hasil wawancara dengan guru kelas tiga.

Dari hasil data ditemukan bahwa pembentukan sikap toleransi dan bersahabat dilakukan dalam tiga model: Pertama, proses pembelajaran diadakan melalui pengembangan kurikulum berbasis pembentukan sikap kemudian dituangkan kedalam silabus dan rencana pelaksanaan pembelajaran. Seperti hasil penelitian yang ditemukan oleh Galih dalam Mustikaningrum, Pramusinta, Buamona, Cahyadi, \& Istiqomah (2020) yaitu mengenai perencanaan penguatan karakter yang tertuang dalam silabus dan RPP yang dibuat oleh guru, biasanya guru di MI tersebut membuat perangkat pembelajaran sebelum mulai tahun ajaran baru, kemudian hasilnya dibuat ke dalam buku kurikulum tingkat satuan pendidikan di MI.

Kedua, dalam implementasi pembelajaran pendidikan kewarganegaraan diarahkan kepada pengelompokan siswa agar lebih mudah memahami materi yang di ajarkan dalam bentuk teoritis dan dapat melatih anak untuk saling membantu, menghargai, dan menghormati teman yang terdapat pada kelompok tersebut. Penelitian yang dilakukan oleh Mahfiroh (2018) menjelaskan bahwa penanaman nilai karakter bersahabat melalui budaya sekolah ditanamkan dalam proses kegiatan belajar di sekolah berlangsung yang diterapkan oleh setiap siswa agar menumbuhkan rasa saling berinteraksi dengan baik, bergaul dengan cinta kasih, menghargai, dan memiliki rasa toleransi sesama teman. Dalam bentuk pelaksanaannya, Mi Tarbiyatul Aulad dan SDN Cimandala 03 mengupayakan pembentukan sikap toleransi dan bersahabat dengan dilaksanakan dalam tiga agenda yang merupakan pendukung dari penanaman sikap, antara lain: (a) pentas seni beragam budaya. (b) santunan kepada fakir miskin tanpa melihat suku dan ras agama. (c) perayaan hari nasional dengan menampilkan budaya sesuai dengan suku dan budaya mereka berasal. (d) pembuatan buku penghubung yang bertujuan untuk memberikan pesan kepada orang tua siswa, yang dalam buku penghubung tersebut terdapat perintah kegiatan yang harus dilakukan oleh orang tua dan siswa sebagai upaya penanaman karakter yang sudah guru lakukan di sekolah untuk ditanamkan kembali di rumah masing-masing siswa. Penelitian yang dilakukan Yunida (2017) menemukan beberapa metode yang dapat diterapkan oleh orang tua dalam membentuk sikap toleransi, yaitu: (1) membiasakan anak untuk bertutur kata sopan dan bersikap yang santun, (2) membiasakan anak untuk berinteraksi dengan teman sebaya, dan (3) memberikan kesempatan anak untuk bersosialisasi dengan orang lain baik itu teman sebaya ataupun orang lebih tua dan muda dari dirinya.

Ketiga, evaluasi. Evaluasi digunakan untuk mengukur keberhasilan pembelajaran yang bertujuan pembentukan sikap dengan implementasi di lapangan 
dalam bentuk pengamatan guru pada pergaulan sehari-hari dan kemampuan menjawab dalam persoalan toleransi dan bersahabat melalui toleransi dan bersahabat.

\section{Simpulan}

Berdasarkan dari uraian yang telah dikemukakan di atas, terdapat beberapa kesimpulan yang didapatkan, yaitu: (1) sikap toleransi dan bersahabat dapat terbentuk melalui kegiatan yang diulang terus-menerus, sehingga siswa dapat terbiasa untuk melakukannya dan menerapkannya dalam kehidupan sehari-hari, (2) orang yang dapat berperan penting dalam pembentukan sikap toleransi dan bersahabat siswa adalah guru untuk mengontrol siswa di sekolah dan orang tua untuk mengontrol di rumah dan lingkungan, (3) dalam pembelajaran pendidikan kewarganegaraan dapat terbentuk sikap toleransi dan bersahabat melalui tiga model, yaitu pembentukan sikap pada proses pembelajaran, pembentukan pada pengimplementasian sikap, dan evalusi pembentukan sikap, (4) kesesuaian materi pendidikan kewarganegaraan dapat membantu mempercepat pembentukan sikap toleransi dan bersahabat pada siswa, dan (5) perlunya program khusus dalam sekolah guna mempererat sikap toleransi dan bersahabat pada siswa.

\section{Daftar Pustaka}

Al-Ansori, A. M. (2018). Strategi Pembentukan Karakter Toleransi pada Siswa Sekolah Dasar Multikultur dan Dwibahasa SD Pribadi di Kota Bandung. UMBARA Indonesian Journal of Anthropology, 3(2), 105-116. https://doi.org/10.24198/ umbara.v3i2.29325

Dahlan. (2016). Konsep Pembelajaran Aqidah \& Akhlak. Deepublish CV Budi Utama.

Dahlan. (2017). Membangun Spiritualitas dan Kemuliaan Sikap (Rekonstruksi Pemahaman Aqidah dan Implikasinya). Samudra Biru.

Idris, M. (2013). Hubungan Antara Gaya Hidup Modern dan Prinsip Individualisme terhadap Perilaku Belajar Fisika SMA Negeri 17 Makassar Provinsi Sulawesi Selatan. JPF: Jurnal Pendidikan Fisika, 1(2), 93-106. https://doi.org/10.24252/ jpf.v1i2.1100

Intan, P. S. A. I. N. P., \& Marhaeni, A. A. I. N. (2015). Pengaruh Modal Kerja, Jumlah Tujuan Negara, Jumlah Tenaga Kerja, dan Kurs Dollar Amerika terhadap Nilai Ekspor Kerajinan Bali di Pasar Internasional. E-Jurnal Ekonomi Pembangunan Universitas Udayana, 4(8), 998-1017. https://ojs.unud.ac.id/index.php/eep/ article/view/14821

Mahfiroh, I. F. (2018). Penanaman Nilai Karakter Bersahabat dan Tanggung Jawab melalui Budaya Sekolah di SMP Al Islam Kartasura [Universitas Muhammadiyah Surakarta]. http://eprints.ums.ac.id/65246/

Mahpudz, A., Jamaludin, \& Palimbong, A. (2019). Tolerance Learning to Develop Students Social Skills in the 21st Century. Advances in Social Science, Education and Humanities Research, 458, 169-178. https://doi.org/10.2991/ assehr.k.200803.022

Marwa, Munirah, Angriani, A. D., Suharti, Sriyanti, A., \& Rosdiana. (2020). Peran Guru dalam Meningkatkan Minat Belajar Peserta Didik Kelas IV pada Masa Pandemi Covid-19. AULADUNA: Jurnal Pendidikan Dasar Islam, 7(2), 215227. https://doi.org/10.24252/10.24252/auladuna.v7i2a10.2020

Musanna, A. (2017). Indigenisasi Pendidikan: Rasionalitas Revitalisasi Praksis 
Pendidikan Ki Hadjar Dewantara. Jurnal Pendidikan dan Kebudayaan, 2(1), 117-133. https://doi.org/10.24832/jpnk.v2i1.529

Mustikaningrum, G., Pramusinta, L., Buamona, S. A. M. U., Cahyadi, E., \& Istiqomah, W. (2020). Implementasi Pendidikan Karakter Terintegrasi Kurikulum dan Metode Pembelajaran pada Masa Pandemi Covid-19. AULADUNA: Jurnal Pendidikan Dasar Islam, 7(2), 154-164. https://doi.org/10.24252/auladuna.v7i2 a5.2020

Nata, A. (2015). Akhlak Tasawuf dan Karakter Mulia. PT Raja Grafindo Persada.

Pranata, Y. Y., \& Barus, G. (2019). Peningkatan Karakter Bersahabat melalui Layanan Bimbingan Kelasikal dengan Pendekatan Experiential Learning. SOLUTION, Jurnal of Counseling and Personal Development, 1(1), 1-14. https://ejournal.usd.ac.id/index.php/solution/article/view/1990

Purwanto, A., Ichsan, I. Z., Gomes, P. W. P., Rahman, M. M., \& Irwandani. (2020). ESBOR During Covid-19: Analysis Students Attitude for Develop 21st Century Environmental Learning. Journal of Sustainability Science and Management, 15(7), 20-29. https://doi.org/10.46754/jssm.2020.10.003

Rahman, A. A. (2018). Psikologi Sosial. Rajawali Pers.

Rahman, M. M. (2019). Secondary School Students Attitude towards Junior School Certificate (JSC) Examination in Bangladesh. International Journal of Education, 11(2), 158-168. https://doi.org/10.17509/ije.v11i2.14746

Rijali, A. (2018). Analisis Data Kualitatif. Jurnal Alhadharah, 17(33), 81-95. https://doi.org/10.18592/alhadharah.v17i33.2374

Salim, M. (2017). Bhinneka Tunggal Ika sebagai Perwujudan Ikatan Adat-Adat Masyarakat Adat Nusantara. Al Daulah: Jurnal Hukum Pidana dan Ketatanegaraan, 6(1), 65-74. https://doi.org/10.24252/ad.v6i1.4866

Shaukat, S., \& Pell, A. W. (2020). Religious Tolerance of Madrasa Students According to Their Religious Affiliation: An Empirical Investigation. International Journal of Islam in Asia, 1(1), 67-90. https://doi.org/10.1163/25899996-01010005

Subianto, J. (2013). Peran Keluarga, Sekolah, dan Masyarakat dalam Pembentukan Karakter Berkualitas. 8(2), 331-354. http://doi.org/10.21043/edukasia.v8i2. 757

Sujana, I. W. C. (2019). Funsi dan Tujuan Pendidikan Indonesia. ADI WIDYA: Jurnal Pendidikan Dasar, 4(1), 29-39. http://doi.org/10.25078/aw.v4i1.927

Sunarti. (2019). Pembentukan Karakter Peserta Didik pada Mata Pelajaran Pendidikan Kewarganegaraan Kelas III A di MI Muhammadiyah Pasirmuncang Purwokerto Barat [Institut Agama Islam Negeri Purwokerto]. http://repository.iain purwokerto.ac.id/5061/1/COVER_BAB I_BAB V_DAFTAR PUSTAKA.pdf

Supardi, U. S. (2015). Arah Pendidikan di Indonesia dalam Tataran Kebijakan dan Implementasi. Jurnal Formatif, 2(2), 111-121. https://doi.org/10.30998/formatif .$v 2 \mathrm{i} 2.92$

Taş, H., \& Minaz, M. B. (2019). The Impact of Biography-based Values Education on 4th Grade Elementary School Students' Attitudes towards Tolerance Value. International Journal of Progressive Education, 15(2), 118-139. https://doi.org/ 10.29329/ijpe.2019.189.9

Tilaar, H. A. R. (2012). 10 Windu Pendidikan Nasional: Arah Ke Mana? Kompas.

Wijaya, R., Fahreza, F., \& Kistian, A. (2019). Penerapan Model Pembelajaran Problem Based Learning (PBL) untuk Mengembangkan Karakter Toleransi dan Demokrasi Siswa pada Pembelajaran PKn Kelas V di SD Negeri Paya Peunaga. Bina Gogik, 6(2), 49-60. http://download.garuda.ristekdikti.go.id/article. php? 
article $=1277585 \& \mathrm{val}=16971 \&$ title $=$ PENERAPAN $\% 20$ MODEL $\% 20 P E M B E L A$ JARAN\%20PROBLEM\%20BASED\%20LEARNING\%20PBL\%20UNTUK\%2 OMENGEMBANGKAN\%20KARAKTER\%20TOLERANSI\%20DAN\%20DE MOKRATIS\%20SISWA\%20PADA\%20PELAJARAN\%20PKn\%20KELAS\%2 0V\%20DI\%20SD\%20NEGERI\%20PAYA\%20PEUNAGA

Yunida. (2017). Membentuk Sikap Toleransi Anak melalui Peran Orang Tua di Perum Pemda Way Huwi Kecamatan Jati Agung Lampung Selatan [Universitas Islam Negeri Raden Intan]. http://repository.radenintan.ac.id/2401/1/SKRIPSI_FIX_ YUNIDA.pdf

Zaman, B. (2019). Urgensi Pendidikan Karakter yang Sesuai dengan Falsafah Bangsa Indonesia. AL GHAZALI, Jurnal Kajian Pendidikan Islam dan Studi Islam, 2(1), 16-31. https://www.ejournal.stainupwr.ac.id/index.php/al_ghzali/article/view/ 101 